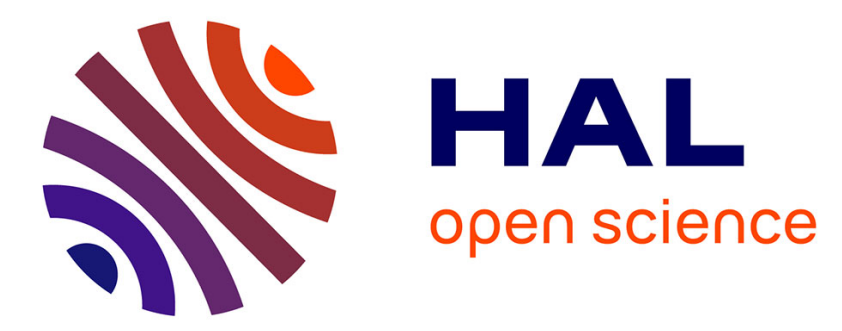

\title{
Metals distribution in colorectal biopsies: New insight on the elemental fingerprint of tumour tissue
}

L. Rinaldi, G. Barabino, J.-P. Klein, D. Bitounis, J. Pourchez, V. Forest, L. Leclerc, G. Sarry, X. Roblin, M. Cottier, et al.

\section{- To cite this version:}

L. Rinaldi, G. Barabino, J.-P. Klein, D. Bitounis, J. Pourchez, et al.. Metals distribution in colorectal biopsies: New insight on the elemental fingerprint of tumour tissue. Digestive and Liver Disease, 2015, 47 (7), pp.602-607. 10.1016/j.dld.2015.03.016 . hal-01215476

\author{
HAL Id: hal-01215476 \\ https://hal.science/hal-01215476
}

Submitted on 16 Oct 2015

HAL is a multi-disciplinary open access archive for the deposit and dissemination of scientific research documents, whether they are published or not. The documents may come from teaching and research institutions in France or abroad, or from public or private research centers.
L'archive ouverte pluridisciplinaire HAL, est destinée au dépôt et à la diffusion de documents scientifiques de niveau recherche, publiés ou non, émanant des établissements d'enseignement et de recherche français ou étrangers, des laboratoires publics ou privés. 
Metals distribution in colorectal biopsies: new insight on the elemental fingerprint of tumor tissue

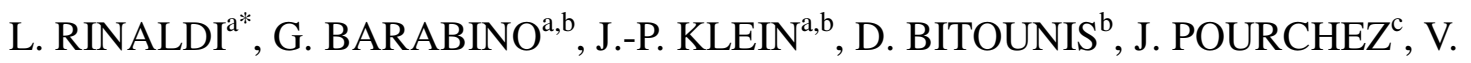

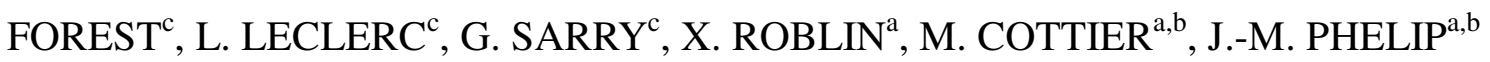

${ }^{a}$ University Hospital CHU Saint-Etienne, F-42055, France

${ }^{\mathrm{b}}$ University of Lyon, F-42023 Saint-Etienne, Jean Monnet University, EA 4624 - LINA, SFR FED 4166 - IFRESIS

${ }^{c}$ Ecole Nationale Supérieure des Mines, CIS-EMSE, EA 4624 - LINA, SFR FED 4166 IFRESIS, F-42023 Saint-Etienne, France

*Corresponding author: Leslie RINALDI

Tel.: +33477826091

Email: leslie.rinaldi@gmail.com 


\section{Abstract}

Background: Colorectal cancer is considered to be an environmental disease. In this context, the study of environmental risk factors associated with the presence of chemical elements is important, as well as improving our knowledge of the elemental fingerprint of tumor tissue compared to non-cancer tissue.

Aims: The objective was to evaluate the element distribution in colorectal adenocarcinoma biopsies, adjacent non-tumor tissues, and healthy controls (non-cancer colorectal biopsies including occlusion or ischemic colons).

Methods: The study is a case-control study which compared the element distribution in colon biopsies from two groups of patients: with colorectal cancer and without colorectal cancer. Patients with colorectal cancer provided 2 different groups of samples: colorectal cancer biopsies and adjacent non-tumor tissues. 15 metal concentrations (Al, B, Cd, Cr, $\mathrm{Cu}, \mathrm{Fe}, \mathrm{Mg}, \mathrm{Mn}, \mathrm{Ni}, \mathrm{Pb}, \mathrm{Se}, \mathrm{Si}, \mathrm{Ti}, \mathrm{V}$, and $\mathrm{Zn}$ ) in colorectal biopsies were quantified by using acid digestion procedures and then inductively coupled plasma (ICP) atomic emission spectrometry.

Results: A total of 104 patients were included. 76 patients in the colorectal cancer group (i.e. tumor and adjacent non-tumor tissues) and 28 patients in the healthy control group (i.e. noncancer colorectal biopsies). Among the 15 elements analyzed by ICP spectrometry, only boron, chromium, zinc, silicon, and magnesium were found in colorectal tissue at clearly detectable concentrations. Our data indicated that colorectal tumor biopsies have significantly elevated concentrations of magnesium as compared to adjacent non-tumor or healthy tissues. Zinc concentration followed the same trend but differences were not statistically significant. In addition, silicon appears to be more accumulated in colorectal cancer tissue than in healthy non-cancer tissue, while chromium was mostly found in adjacent non-tumor tissue. 
Conclusion: Magnesium, chromium, zinc and silicon were found in noteworthy concentrations in colorectal tumor. Their potential role in colorectal carcinogenesis should be explored.

Keywords: elemental analysis, environmental risk, magnesium, colorectal cancer 


\section{Introduction}

Colorectal cancer accounts for over $9 \%$ of all cancer incidences. In the European Union, it is the third most common cancer diagnosis among men and women [1]. This worldwide mortality is approximately half that of the incidence (i.e. about $4.5 \%$ ). Several risk factors are associated with the incidence of colorectal cancer. Among them, the nonmodifiable risks (i.e., those that an individual cannot control) include age and genetic. Hereditary factors, which are involved in 5\% of colorectal cancers, are represented by family susceptibility, familial adenomatous polyposis, and Lynch syndrome. Some digestive diseases are predictive factors of colorectal cancer, including chronic bowel diseases (Crohn's disease and hemorrhagic rectocolitis). However, colorectal cancer is also considered to be an environmental disease. Thus, several lifestyle-related factors have also been identified, such as nutritional practices, physical activity and obesity, cigarette smoking, and heavy alcohol consumption. Although numerous environmental risk factors may play an important role, those risk factors identified do not fully explain the frequency of colorectal cancer. Occupational studies have tentatively linked colorectal cancer to asbestos $[2,3]$ and to metal dust [4]. Hence, a new field is receiving increasing attention, namely the study of environmental risk factors associated with the presence of chemical elements $[5,6]$, such as exogenous micro- and nanoparticles [7].

Some elements are essential for numerous metabolic and physiological processes in the body, as well as the synthesis and structural stabilization of enzymes, proteins, and nucleic acids. For example, $\mathrm{Zn}$ is essential for the functioning of more than 300 enzymes [8] and elements such as $\mathrm{Cu}, \mathrm{Fe}, \mathrm{Mg}, \mathrm{Ni}$, and $\mathrm{Zn}$ form compounds with proteins that have important catalytic functions. Cancer is fundamentally a disease of tissue growth regulation. During tumorigenesis, some metal ions (e.g., $\mathrm{Fe}, \mathrm{Mg}, \mathrm{Ni}, \mathrm{Zn}$ ) induce binding competition 
with chromatin (e.g., DNA, histones, transcription factors, DNA repair enzymes) and other regulatory molecules that first give rise to tumors and then are responsible for controlling tumor growth. In addition, many studies have identified metal-induced carcinogenicity, demonstrating strong oxidative stress induced by elements such as $\mathrm{Cd}, \mathrm{Co}, \mathrm{Cr}, \mathrm{Cu}, \mathrm{Fe}$, and Ni. Free radicals are highly reactive chemical species that have the potential to harm cells, including damage that may lead to cancer. In fact, the generation of reactive oxygen species (ROS) can cause DNA damage and enhance lipid peroxidation. The first-line antioxidant defense of the organism interacts with and neutralizes the effects of ROS, thus preventing them from causing damage. Antioxidants are also known as "ROS scavengers." However, many antioxidant enzymes, such as superoxide dismutases, have an active metal center $(\mathrm{Cu}$, $\mathrm{Mn}$, or $\mathrm{Zn}$ ). So, the metal element concentrations in tissues can have a strong impact both on the oxidative stress and the antioxidant defense system. In other words, an imbalance in the optimum level of certain elements may lead to colon carcinogenesis due to a poor redox regulation. However, data on the elemental concentration ranges in human colorectal biopsies are scarce and fragmentary. As a result, a main challenge is to improve our knowledge of the elemental fingerprint of tumor tissue compared to non-cancer tissue.

The aim of this study was to evaluate the element distribution in colorectal adenocarcinoma biopsies, adjacent non-tumor tissues, and healthy controls. To do so, we investigated the elemental distribution in colorectal biopsies of cancer patients (i.e., in tumor and adjacent non-tumor tissues) compared to those of healthy controls (occlusion or ischemic colons). We used the same patients for evaluating the concentrations of various elements (Al, $\mathrm{B}, \mathrm{Cd}, \mathrm{Cr}, \mathrm{Cu}, \mathrm{Fe}, \mathrm{Mg}, \mathrm{Mn}, \mathrm{Ni}, \mathrm{Pb}, \mathrm{Se}, \mathrm{Si}, \mathrm{Ti}, \mathrm{V}$, and $\mathrm{Zn}$ ) in cancer and non-cancer tissue, this way allowing for a reliable comparison with potential biases such as genetic, environmental, or dietary factors being eliminated. 


\section{Methods}

\section{Patients}

This case-control study was performed in the Digestive Surgery and Gastroenterological Departments of the University Hospital of Saint Etienne (France). To avoid the bias of selection, the clinical protocol was proposed to each collectomized patient between March 2011 and June 2013 at the University Hospital of Saint Etienne. Patients were considered for the study if they were at least 18 years old and an affiliated member of the social security system at the time of the surgical procedure, which included total or partial colectomy. Before inclusion, each patient provided written informed consent. The exclusion criteria were refused consent, patients under guardianship, rectal cancers initially irradiated, adenomatous polyposis, inflammatory bowel disease (i.e., Crohn's disease or hemorrhagic rectocolitis), familial adenomatous polyposis, or Lynch syndrome. Data on patients' treatment were collected.

A total of 104 patients were included. The colorectal cancer group comprised 76 patients. A first colorectal biopsy was performed within the tumor area, and a second was performed within adjacent non-tumor (i.e., peritumor) tissues. Patients were eligible for inclusion in the colorectal cancer group if the histological findings confirmed the cancer as an adenocarcinoma, regardless of the tumor staging. The control group comprised 28 patients with occlusion or ischemic colons. Patients were eligible for inclusion in the control group if they underwent a colectomy for any etiology except colorectal cancer or inflammatory bowel diseases. Histological analysis of all colorectal biopsies included in this study was performed at the Anatomopathology Department.

\section{Sampling and conservation of samples}


The colorectal biopsies were transported to the Anatomopathology Department in sterile packaging without being fixed. The colectomies were put on a sterile sheet and manipulated with sterile and disposables scissors, pliers, and bistouries. Pieces of colectomy were opened following the central line of haustrations. In case of tumor invasion of this line, the tumor was avoided in order not to disseminate tumor cells remotely. For the patients in the colorectal cancer group, we performed a mucosal biopsy (about $1 \mathrm{~cm}^{2}$ and $0.2 \mathrm{~g}$ ) in the tumor area and in the adjacent non-tumor tissue; in the latter case, the biopsy was taken at least $10 \mathrm{~cm}$ away from the tumor tissue area. For the control group, one mucosal colic biopsy (about $1 \mathrm{~cm}^{2}$ and $0.2 \mathrm{~g})$ was performed. Consequently, three groups of biopsies were collected: (1) colorectal biopsies from tumor tissue, (2) colorectal biopsies from adjacent non-tumor tissue, and (3) colorectal biopsies from non-cancer patients (i.e., healthy tissue). Colorectal biopsies were rinsed thoroughly with sterile water, placed into sterile standard containers, and snap-frozen with liquid nitrogen at $-196^{\circ} \mathrm{C}$ until later analysis.

\section{Element analysis}

To avoid classification bias, the multi-element analysis was performed in a blind manner by a technician. Acid digestion procedures are necessary to quantify elements in organic samples using atomic spectrometric methods such as inductively coupled plasma atomic emission spectrometry (ICP-AES). This mineralization step allows complete transfer of the analytes into solution, so that they can be dosed in liquid form. As a result, the goal of the digestion procedure is to obtain the complete dissolution of the analytes and complete decomposition of the organic matrix, while avoiding loss or contamination of analytes.

Each colorectal sample was thawed and weighed. For the acid digestion, biopsies were placed individually in a small Petri dish previously rinsed with $70 \%$ alcohol. First, a mechanical dissolution was performed by dilacerating biopsies with disposable sterile 
scalpels. Then $3 \mathrm{M} \mathrm{HCl}$ was introduced, and samples were incubated overnight under soft agitation. The next day, the supernatant and remaining tissue debris were placed into Salivex tubes for ICP-AES analysis. Tubes were heated on a hotplate $\left(99^{\circ} \mathrm{C}\right)$ until all the liquid had evaporated. Finally, samples were put into suspension in $10 \mathrm{ml}$ of $2 \mathrm{M} \mathrm{HCl}$ and preserved at $4^{\circ} \mathrm{C}$ until ICP-AES analysis. There was no further analytical dilution.

ICP-AES was used to quantify the concentrations of minor elements in each colorectal biopsy. Based on previously published data [6] we investigated the presence of 15 elements. Each element has a specific limit of detection (LoD, concentration of elements expressed in parts per billion i.e. in ng per g of wet tissue): aluminum (LoD of $14.1 \mathrm{ng} / \mathrm{g}$ ), boron (LoD of $1.5 \mathrm{ng} / \mathrm{g}$ ), cadmium (LoD of $1.3 \mathrm{ng} / \mathrm{g}$ ), chromium (LoD of $2.8 \mathrm{ng} / \mathrm{g}$ ), copper (LoD of 2.4 $\mathrm{ng} / \mathrm{g}$ ), iron (LoD of $1 \mathrm{ng} / \mathrm{g}$ ), magnesium (LoD of $0.1 \mathrm{ng} / \mathrm{g}$ ), manganese (LoD of $0.2 \mathrm{ng} / \mathrm{g}$ ), nickel (LoD of $4.1 \mathrm{ng} / \mathrm{g}$ ), lead (LoD of $25.1 \mathrm{ng} / \mathrm{g}$ ), selenium (LoD of $58.3 \mathrm{ng} / \mathrm{g}$ ), silicon (LoD of $4.4 \mathrm{ng} / \mathrm{g}$ ), titanium (LoD of $0.6 \mathrm{ng} / \mathrm{g}$ ), vanadium (LoD of $3.6 \mathrm{ng} / \mathrm{g}$ ), and zinc (LoD of 0.8 $\mathrm{ng} / \mathrm{g}$ ). Results of concentration of minor element in each colorectal biopsy are expressed in parts per million (i.e. ppm or $\mu \mathrm{g}$ of element per $\mathrm{g}$ of wet tissue). A negative control was performed for each series of analyses. This negative control aimed at evaluating the background noise due to the presence of metallic impurities into the biopsy tubes and all the devices in contact with the biopsy especially in the operating room (scalpel ...) and/or the possible contamination of analytes during the acid digestion procedure just before the ICP quantification. This negative control can be a crucial step in order to differentiate the elements coming from colorectal biopsies from a possible pollution of samples during the analytical procedure.

\section{Statistical analysis}

Statistical analysis was performed on the elements that had detectable concentrations and 
were above the negative control. We compared the elemental fingerprints between three sets of biopsies: (1) healthy tissue versus tumor tissue, (2) tumor tissue versus adjacent non-tumor tissue, and (3) adjacent non-tumor tissue versus healthy tissue. The normality of the variable distribution was assessed with the Kolmogorov-Smirnov test. The median and mean concentrations that had a normal distribution were compared between groups with the Z-test, whereas the others were compared by using the Wilcoxon test for matched series and the Mann-Whitney test for independent series. The significance of relationships between variables was examined by using Student's $t$-test on the correlation coefficients. The comparison between colorectal cancer patients and the control group was performed with the $Z$-test or the Mann-Whitney test. For all analyses, a $p$ value $<0.05$ was considered to be significant.

\section{Results}

The characteristics of the two patient groups were comparable except for age $(\mathrm{p}<0.001)$ (Table 1). The significant age difference between the two groups can be explained epidemiologically: the mean age of colorectal cancer patients is around 70 years (this study, 75 years), whereas it is around 55 years for occlusion or ischemic colons (control group mean, 60 years). In addition, the two groups had a similar proportion of males to females, and both reflected the fact that colorectal cancer as well as occlusion or ischemic colons are more prevalent in men than in women.

Among the 15 elements of interest, only $\mathrm{B}, \mathrm{Cr}, \mathrm{Mg}, \mathrm{Si}$, and $\mathrm{Zn}$ occurred at concentrations above the trace element quantification obtained for the negative control. For these 5 elements, the concentrations found in our study were 1000000 times the LoD for Mg, 10000 times the LoD for Zn, 1000 times the LoD for Si and Cr, and 10 times the LoD 
for $\mathrm{B}$. It should be noted that $\mathrm{Cu}$ and $\mathrm{Fe}$ were quantified but their median concentrations for all samples (4.5 [Interquartile Range $=3.8] \mu \mathrm{g} / \mathrm{g}$ and $89 ; 2[69.1] \mu \mathrm{g} / \mathrm{g}$ respectively) were found to be close to concentrations obtained in the negative control experiments (background noise) which make them impossible to interpret.

\section{Concentrations in tumor tissue versus healthy tissue}

A significantly higher $\mathrm{Mg}$ and $\mathrm{Si}$ concentrations were found in the colorectal tumor tissue than in the healthy tissue (Fig. 1, 2 and 3, Table 2). Although the $\mathrm{Zn}$ and $\mathrm{Cr}$ concentrations were also higher in the tumor tissue than in the healthy tissue, the differences were not significant ( $p=0.51$ and $p=0.30$, respectively). Finally, the median concentration of B was lower than $0.5 \mu \mathrm{g} / \mathrm{g}$ in each group and was similar in the tumor and healthy tissues $(p=0.62)$.

\section{Concentrations in tumor tissue versus adjacent non-tumor tissue}

The Mg concentration was significantly greater in the tumor tissue than in the adjacent nontumor tissue, with median concentrations of 147.0 [52.2] and 114.6 [38.8] $\mu \mathrm{g} / \mathrm{g}$ respectively $(p=0.0008$ : Fig. 2; Table 2). Zn was also higher in the tumor tissue than in the adjacent nontumor tissue; however the differences did not reach the level of significance $(p=0.1143)$. The Cr concentration followed an opposite trend: 7.9 [8.8] $\mu \mathrm{g} / \mathrm{g}$ in the tumor tissue and 10.0 [9.1] $\mu \mathrm{g} / \mathrm{g}$ in the adjacent non-tumor tissue $(p=0.0433)$. Si and $\mathrm{B}$ concentrations exhibited no significant difference between the two tissue types ( $p=0.4445$ and $\mathrm{p}=0.6182$, respectively).

\section{Correlation analyses}

Because there was a predictable difference of age between the two patient groups, we examined whether there was a link between the age of patients and the $\mathrm{Mg}, \mathrm{Zn}$, and $\mathrm{Si}$ concentrations. No relationship was noted for $\mathrm{Mg}, \mathrm{Cr}$ or Si concentrations (Mg vs. age: $r=$ 
$0.13, p=0.18$; Cr vs. age: $r=-0.15, p=0.14$; Si vs. age: $r=0.1, p=0.32$ ), whereas a weak inverse correlation was found for $\mathrm{Zn}(r=-0.24, p=0.01)$ : the more a patient aged, the greater the Zn deficiency was (Fig. 4).

\section{Discussion}

The aim of our study was to evaluate the element distribution in colorectal adenocarcinomas, adjacent non-tumor tissues, and healthy controls. Among the 15 elements analyzed by ICP-AES, only $\mathrm{B}, \mathrm{Cr}, \mathrm{Zn}, \mathrm{Si}$, and $\mathrm{Mg}$ were found in colorectal tissue at clearly detectable concentrations. It should be noted that $\mathrm{Cu}$ and $\mathrm{Fe}$ were quantified but their concentrations were found to be close to concentrations obtained in the negative control experiments. Comparison between groups showed that patients with colorectal cancer had higher $\mathrm{Mg}, \mathrm{Zn}, \mathrm{Si}$ and $\mathrm{Cr}$ concentrations in their biopsies than others, even if these differences were only statistically significant for $\mathrm{Mg}$ and $\mathrm{Si}$. The differences of concentration between colorectal tumor biopsies and adjacent non-tumor biopsies were clearly elementdependent. As a matter of fact $\mathrm{Mg}$ concentration was significantly higher in tumor biopsies while Cr was significantly lower. Besides, there were no significant statistical differences between $\mathrm{Si}$ and $\mathrm{Zn}$ concentration quantified in tumor tissues and adjacent non-tumor tissues . However, a slight tendency seemed to indicate a $\mathrm{Zn}$ concentration higher in tumor biopsies than in adjacent non-tumor biopsies. Even if our study design does not allow us to draw conclusions about a possible involvement of $\mathrm{Mg}, \mathrm{Cr}, \mathrm{Si}$ and $\mathrm{Zn}$ elements in the development of colorectal tumor, the rise of their concentration in colorectal biopsies intrigues.

Some other studies have already examined the element fingerprints of colorectal biopsies. Overall the amount of elements found in these studies was slightly higher than in ours. A possible explanation is that most studies worked on dry tissue while we worked on wet tissue. Bocca [6] used ICP spectrometry to determine the concentrations of 30 elements 
in colorectal biopsies of healthy patients. Median $\mathrm{Mg}, \mathrm{Zn}$ and $\mathrm{Cr}$ concentration were respectively $1090 \mu \mathrm{g} / \mathrm{g} ; 86.5 \mu \mathrm{g} / \mathrm{g}$ and $343 \mathrm{ng} / \mathrm{g}$. Lavilla et al. [5] assayed 18 elements in biopsies from 38 patients with colorectal cancer, revealing that the tumor tissue may accumulate trace of minor elements, especially $\mathrm{Mg}(573 \mu \mathrm{g} / \mathrm{g}$ in tumor tissues vs. $296 \mu \mathrm{g} / \mathrm{g}$ in healthy controls). In Lavilla et al. study, there was no significative difference for $\mathrm{Zn}(90 \mu \mathrm{g} / \mathrm{g}$ in tumor tissue vs. $79 \mu \mathrm{g} / \mathrm{g}$ in healthy tissue). Their findings are consistent with our results. Alimonti et al. [9] examined the involvement of metals in colorectal polyps and found that Mg median concentration (from 1045 to $1283 \mu \mathrm{g} / \mathrm{g}$ ) and $\mathrm{Zn}$ median concentration (89 to 102 $\mu \mathrm{g} / \mathrm{g}$ ) were not significantly different between polypes, adjacent non-polype tissues and healthy controls. Although, $\mathrm{Cr}$ has only been found at trace level, it was significantly lower in polype than in adjacent non-polype tissues (455 vs. $163 \mathrm{ng} / \mathrm{g}$ ). In two different studies, Kucharzewski et al. determined the concentrations of $\mathrm{Fe}, \mathrm{Se}, \mathrm{Zn}$ and $\mathrm{Cu}$ in colorectal polype and cancer. They found that $\mathrm{Fe}$ and $\mathrm{Zn}$ mean concentration were higher in cancer than in polype $(46.1 \mu \mathrm{g} / \mathrm{g}$ vs. $43.2 \mu \mathrm{g} / \mathrm{g}$ and $14.8 \mu \mathrm{g} / \mathrm{g}$ vs. $9.84 \mu \mathrm{g} / \mathrm{g}$ respectively). Overall, the results of those previous studies are quite consistent with ours.

Several Japanese studies revealed that a diet with a low Mg content is a potential risk factor of colon cancer, although the results were not significant for rectum cancers [10-14]. Similar results were observed on the impact of $\mathrm{Mg}$ concentration in drinking water $[15,16]$, whereas another study found no such influence of $\mathrm{Mg}$ on colorectal adenoma [9]. Studies on mice using a diet supplemented with $\mathrm{Mg}$ found a protective role of $\mathrm{Mg}$, as an antioxidant that inhibits oncogenes [17]. A meta-analysis of studies (8000 colorectal cancers in 338,797 patients) suggested a protective effect of $\mathrm{Mg}$ in colon cancers, although those results were not significant for rectal cancers [18]. However, the role of $\mathrm{Mg}$ could be complex, with a protective effect at the beginning of carcinogenesis and a pro-oncogenic role at the ultimate stages promoting cellular division [19]. We know that the dissemination of neoplastic cells 
during surgery can lead to the development of metastasis via the adhesion of cells. This adhesion process is principally induced by integrins and matrix receptors that are influenced by divalent cations. A study suggested that the high content of $\mathrm{Mg}^{2+}$ in endogenous wound fluid may potentiate tumor cell adhesion, whereas $\mathrm{Ca}^{2+}$ may inhibit it [20]. Consequently, it was proposed that irrigating with dilute $\mathrm{CaCl}_{2}$ could decrease local tumor recurrence by inhibiting the adhesion of tumor cells. Another explanation of the abundance of $\mathrm{Mg}$ in colorectal tumor could be an accumulation of $\mathrm{Mg}$ due to the cancerous process. In this case, $\mathrm{Mg}$ accumulation would be a consequence of the cancer not a cause.

Few studies have examined Zn profiles. Our results suggest a correlation between $\mathrm{Zn}$ concentration and the age of patients, and indeed Zn deficiency is more frequent in the elderly [21]. According to a literature review, the role of $\mathrm{Zn}$ in carcinogenesis is not well understood [22]. Some authors proposed that $\mathrm{Zn}$ is not related to colorectal cancer [23], others that $\mathrm{Zn}$ could inhibit the growth of neoplastic cells [24,25] and others found higher Zn blood concentrations in rats with colorectal cancer [26]. Carter et al. showed that a diet low in $\mathrm{Zn}$ favors the development of adenoma and non-invasive cancers, whereas a diet enriched in $\mathrm{Zn}$ favors the development of invasive cancers [27]. The etiologic relationship could not be demonstrated, but the main assumptions concern the role of $\mathrm{Zn}$ in regulating oxidative stress and cell division, proliferation, and DNA replication. In the same way as for magnesium, the design of our study does not allow us to judge if the elevation of $\mathrm{Zn}$ in the tumor is a cause or a consequence of the colorectal cancer development. Indeed, it has been shown that metallothionein which bind Zn accumulate in rapidly proliferating human colonic cancer cells [28].

The different elements found in colon biopsies could be from endogenous (e.g., ions from metabolic and physiological processes) or exogenous sources (e.g., inorganic and nonbiodegradable pollutants of environmental origin). Whereas $\mathrm{Zn}$ and $\mathrm{Mg}$ could be from 
endogenous sources, $\mathrm{Si}$ and $\mathrm{Cr}$ are more probably of exogenous origin. Indeed silica (silicon dioxide) is a common additive in the production of foods, and colloidal silica is also used as a wine, beer, and juice fining agent. Moreover, the detection of Si could suggest a potential role of exogenous micro- or nanoparticles in diseases that usual histopathology exams not take into account. In this context, exposure to ultra-fine particles could be of interest. As a matter of fact, ultra-thin particles are toxicants present in air pollution contributing to asthma, cardiovascular disease, and overall mortality [29]. Significant quantities of titanium dioxide and silicon dioxide are swallowed, both as natural contaminants of food and as additives. More than $10^{12}$ mineral particles per day are ingested, and it is possible that the ingested elements are not as innocuous as we have assumed [7,30-33]. Recent studies have shown that the accumulation of debris from dental prostheses could cause multi-organ parenchymal granulomatosis [34], and several studies have described a relationship between debris from hip prosthesis and local inflammatory reaction with granulomatosis [35,36]. Finally, some other studies, showed that the composition of drinking water and diet with higher or lower concentrations of elements such as $\mathrm{Mg}, \mathrm{Fe}, \mathrm{Cr}$ or $\mathrm{Zn}$ can be associated with colorectal cancer $[12,30,37-39]$.

\section{Conclusion}

Although alterations in element homeostasis and the etiology of cancer are of great interest, the elemental distribution in human colorectal biopsies remains unclear. This study demonstrated that various types of colorectal biopsies have specific elemental fingerprints. We observed significantly higher $\mathrm{Mg}$ concentration and a nearly significantly higher $\mathrm{Zn}$ concentration in adenocarcinoma tissues than in adjacent non-tumor tissues, as well as higher $\mathrm{Si}$ and $\mathrm{Cr}$ concentrations in colorectal cancer than in healthy non-cancer biopsies. $\mathrm{Mg}$ and $\mathrm{Zn}$ 
could be from endogenous sources, whereas $\mathrm{Si}$ and $\mathrm{Cr}$ may be from exogenous sources. Further clinical trials should be dedicated to investigating the impact of $\mathrm{Zn}, \mathrm{Si}, \mathrm{Cr}$ and $\mathrm{Mg}$ at the different steps of the adenoma-carcinoma sequence. Finally, the distribution of chemical elements in colorectal polyps should be investigated as well. 


\section{References}

[1] Cancer colorectal n.d. http://www.euro.who.int/fr/healthtopics/noncommunicable-diseases/cancer/news/news/2012/2/early-detection-ofcommon-cancers/colorectal-cancer (accessed February 1, 2015).

[2] Selikoff IJ, Hammond EC. Asbestos and smoking. JAMA 1979;242:458-9.

[3] Newhouse ML. The asbestos industry and statutory control of its hazards. IARC Sci Publ 1979:59-70.

[4] Berg K. [Editorial: Genetic damage and carcinogenic drugs]. Tidsskr Den Nor Lægeforen Tidsskr Prakt Med Ny Række 1975;95:1995-6.

[5] Lavilla I, Costas M, Miguel PS et al. Elemental fingerprinting of tumorous and adjacent non-tumorous tissues from patients with colorectal cancer using ICP-MS, ICP-OES and chemometric analysis. Biometals Int J Role Met Ions Biol Biochem Med 2009;22:863-75.

[6] Bocca B, Lamazza A, Pino A, et al. Determination of 30 elements in colorectal biopsies by sector field inductively coupled plasma mass spectrometry: method development and preliminary baseline levels. Rapid Commun Mass Spectrom RCM 2007;21:1776-82.

[7] Gatti AM. Biocompatibility of micro- and nano-particles in the colon. Part II. Biomaterials 2004;25:385-92.

[8] Tudor R, Zalewski PD, Ratnaike RN. Zinc in health and chronic disease. J Nutr Health Aging 2005;9:45-51.

[9] Alimonti A, Bocca B, Lamazza A, et al. A study on metals content in patients with colorectal polyps. J Toxicol Environ Health A 2008;71:342-7.

[10] Ma E, Sasazuki S, Inoue M, et al. High dietary intake of magnesium may decrease risk of colorectal cancer in Japanese men. J Nutr 2010;140:779-85.

[11] Folsom AR, Hong C-P. Magnesium intake and reduced risk of colon cancer in a prospective study of women. Am J Epidemiol 2006;163:232-5.

[12] Kuo H-W, Peng C-Y, Feng A, et al. Magnesium in drinking water modifies the association between trihalomethanes and the risk of death from colon cancer. J Toxicol Environ Health A 2011;74:392-403.

[13] Kuo H-W, Chen P-S, Ho S-C, et al. Trihalomethanes in drinking water and the risk of death from rectal cancer: does hardness in drinking water matter? J Toxicol Environ Health A 2010;73:807-18.

[14] Qu X, Jin F, Hao Y, et al. Nonlinear association between magnesium intake and the risk of colorectal cancer. Eur J Gastroenterol Hepatol 2013;25:309-18.

[15] Chiu H-F, Tsai S-S, Wu T-N, Yang C-Y. Colon cancer and content of nitrates and magnesium in drinking water. Magnes Res Off Organ Int Soc Dev Res Magnes 2010;23:81-9.

[16] Yang CY, Hung CF. Colon cancer mortality and total hardness levels in Taiwan's drinking water. Arch Environ Contam Toxicol 1998;35:148-51.

[17] Tanaka T, Shinoda T, Yoshimi N, et al. Inhibitory effect of magnesium hydroxide on methylazoxymethanol acetate-induced large bowel carcinogenesis in male F344 rats. Carcinogenesis 1989;10:613-6.

[18] Chen G-C, Pang Z, Liu Q-F. Magnesium intake and risk of colorectal cancer: a meta-analysis of prospective studies. Eur J Clin Nutr 2012;66:1182-6.

[19] Hartwig A. Role of magnesium in genomic stability. Mutat Res 2001;475:113-21.

[20] Van der Voort van Zyp J, Conway WC, Thamilselvan V, et al. Divalent cations influence colon cancer cell adhesion in a murine transplantable tumor model. Am J 
Surg 2005;190:701-7.

[21] Meunier N, O'Connor JM, Maiani G, et al. Importance of zinc in the elderly: the ZENITH study. Eur J Clin Nutr 2005;59 Suppl 2:S1-4.

[22] John S, Briatka T, Rudolf E. Diverse sensitivity of cells representing various stages of colon carcinogenesis to increased extracellular zinc: implications for zinc chemoprevention. Oncol Rep 2011;25:769-80.

[23] Hara A, Sasazuki S, Inoue M, et al. Zinc and heme iron intakes and risk of colorectal cancer: a population-based prospective cohort study in Japan. Am J Clin Nutr 2012;96:864-73.

[24] Cilla A, Lagarda MJ, Barberá R, Romero F. Polyphenolic profile and antiproliferative activity of bioaccessible fractions of zinc-fortified fruit beverages in human colon cancer cell lines. Nutr Hosp 2010;25:561-71.

[25] Christudoss P, Selvakumar R, Pulimood AB, et al. Zinc and zinc related enzymes in precancerous and cancerous tissue in the colon of dimethyl hydrazine treated rats. Asian Pac J Cancer Prev APJCP 2012;13:487-92.

[26] Gupta SK, Shukla VK, Vaidya MP, et al. Serum and tissue trace elements in colorectal cancer. J Surg Oncol 1993;52:172-5.

[27] Carter JW, Lancaster H, Hardman WE, Cameron IL. Zinc deprivation promotes progression of 1,2-dimethylhydrazine-induced colon tumors but reduces malignant invasion in mice. Nutr Cancer 1997;27:217-21.

[28] Nagel WW, Vallee BL. Cell cycle regulation of metallothionein in human colonic cancer cells. Proc Natl Acad Sci U S A 1995;92:579-83.

[29] European Commission Directorate C Environment and Health. Baseline Scenarios for the Clean Air For Europe (CAFE) Programme. Final Report. International Institute for Applied Systems Analysis (IIASA). 2005.

[30] Schneider JC. Can microparticles contribute to inflammatory bowel disease: innocuous or inflammatory? Exp Biol Med Maywood NJ 2007;232:1-2.

[31] Buzea C, Pacheco II, Robbie K. Nanomaterials and nanoparticles: sources and toxicity. Biointerphases 2007;2:MR17-71.

[32] Urban RM, Jacobs JJ, Tomlinson MJ, et al. Dissemination of wear particles to the liver, spleen, and abdominal lymph nodes of patients with hip or knee replacement. J Bone Joint Surg Am 2000;82:457-76.

[33] Lomer MCE, Thompson RPH, Powell JJ. Fine and ultrafine particles of the diet: influence on the mucosal immune response and association with Crohn's disease. Proc Nutr Soc 2002;61:123-30.

[34] Ballestri M, Baraldi A, Gatti AM, et al. Liver and kidney foreign bodies granulomatosis in a patient with malocclusion, bruxism, and worn dental prostheses. Gastroenterology 2001;121:1234-8.

[35] al-Saffar N, Revell PA. Pathology of the bone-implant interfaces. J Long Term Eff Med Implants 1999;9:319-47.

[36] Revell PA, al-Saffar N, Kobayashi A. Biological reaction to debris in relation to joint prostheses. Proc Inst Mech Eng [H] 1997;211:187-97.

[37] Nelson RL. Dietary iron and colorectal cancer risk. Free Radic Biol Med 1992;12:161-8.

[38] Thompson CM, Proctor DM, Haws LC, et al. Investigation of the mode of action underlying the tumorigenic response induced in B6C3F1 mice exposed orally to hexavalent chromium. Toxicol Sci Off J Soc Toxicol 2011;123:58-70.

[39] Wang X, Mandal AK, Saito H, et al. Arsenic and chromium in drinking water promote tumorigenesis in a mouse colitis-associated colorectal cancer model and 
the potential mechanism is ROS-mediated Wnt/ $\beta$-catenin signaling pathway. Toxicol Appl Pharmacol 2012;262:11-21. 
Table 1. Patient characteristics of the two groups (pTNM: size, nodes, metastasis from the internal classification of tumors; PY: pack-years)

\begin{tabular}{|c|c|c|c|}
\hline \multicolumn{2}{|l|}{ Characteristics } & \multirow{2}{*}{\begin{tabular}{|l}
$\begin{array}{l}\text { Colorectal } \\
\text { cancer }\end{array}$ \\
$54 \%$
\end{tabular}} & \multirow{2}{*}{\begin{tabular}{|l|} 
Control \\
$54 \%$
\end{tabular}} \\
\hline \multirow[t]{2}{*}{ Sex } & Male & & \\
\hline & Female & $46 \%$ & $46 \%$ \\
\hline Mean age (years) & & $75+/-11$ & $60+/-15$ \\
\hline \multirow[t]{4}{*}{ Differentiation } & Poor & $13 \%$ & \\
\hline & Medium & $46 \%$ & \\
\hline & Well & $33 \%$ & \\
\hline & Undefined & $8 \%$ & \\
\hline \multirow[t]{12}{*}{ pTNM } & T1 & $9 \%$ & \\
\hline & $\mathrm{T} 2$ & $20 \%$ & \\
\hline & T3 & $46 \%$ & \\
\hline & $\mathrm{T} 4$ & $25 \%$ & \\
\hline & Tx & 0 & \\
\hline & No & $62 \%$ & \\
\hline & N1 & $22 \%$ & \\
\hline & $\mathrm{N} 2$ & $16 \%$ & \\
\hline & $\mathrm{Nx}$ & 0 & \\
\hline & M0 & $58 \%$ & \\
\hline & M1 & $34 \%$ & \\
\hline & $\mathrm{Mx}$ & $8 \%$ & \\
\hline \multirow[t]{2}{*}{ Tobacco } & $N$ & $41 \%$ & $50 \%$ \\
\hline & Mean consumption in PY & $31+/-21$ & $28+/-27$ \\
\hline \multirow[t]{2}{*}{ Alcohol } & $N$ & $33 \%$ & $29 \%$ \\
\hline & Mean drink (g/day) & $55+/-41$ & $31+/-28$ \\
\hline
\end{tabular}


Table 2. Median concentrations ( $\mu \mathrm{g}$ of element per $\mathrm{g}$ of wet tissue) and [interquartile range] of $\mathrm{Mg}, \mathrm{Zn}$, and $\mathrm{Si}$

\begin{tabular}{|l|l|l|l|}
\hline & Tumor tissue & $\begin{array}{l}\text { Adjacent non- } \\
\text { tumor tissue }\end{array}$ & Healthy tissue \\
\hline $\mathrm{Mg}$ & $147.0[52.2]$ & $114.6[38.8]$ & $103.3[37.1]$ \\
\hline $\mathrm{Zn}$ & $19.7[12.5]$ & $17.2[9.4]$ & $15.7[12.9]$ \\
\hline $\mathrm{Si}$ & $22.3[29.9]$ & $23.8[26.0]$ & $11.2[11.8]$ \\
\hline $\mathrm{Cr}$ & $7.9[8.8]$ & $10.0[9.1]$ & $5.7[3.9]$ \\
\hline $\mathrm{B}$ & $0.4[4.1]$ & $0.3[3.2]$ & $0.4[1.5]$ \\
\hline
\end{tabular}




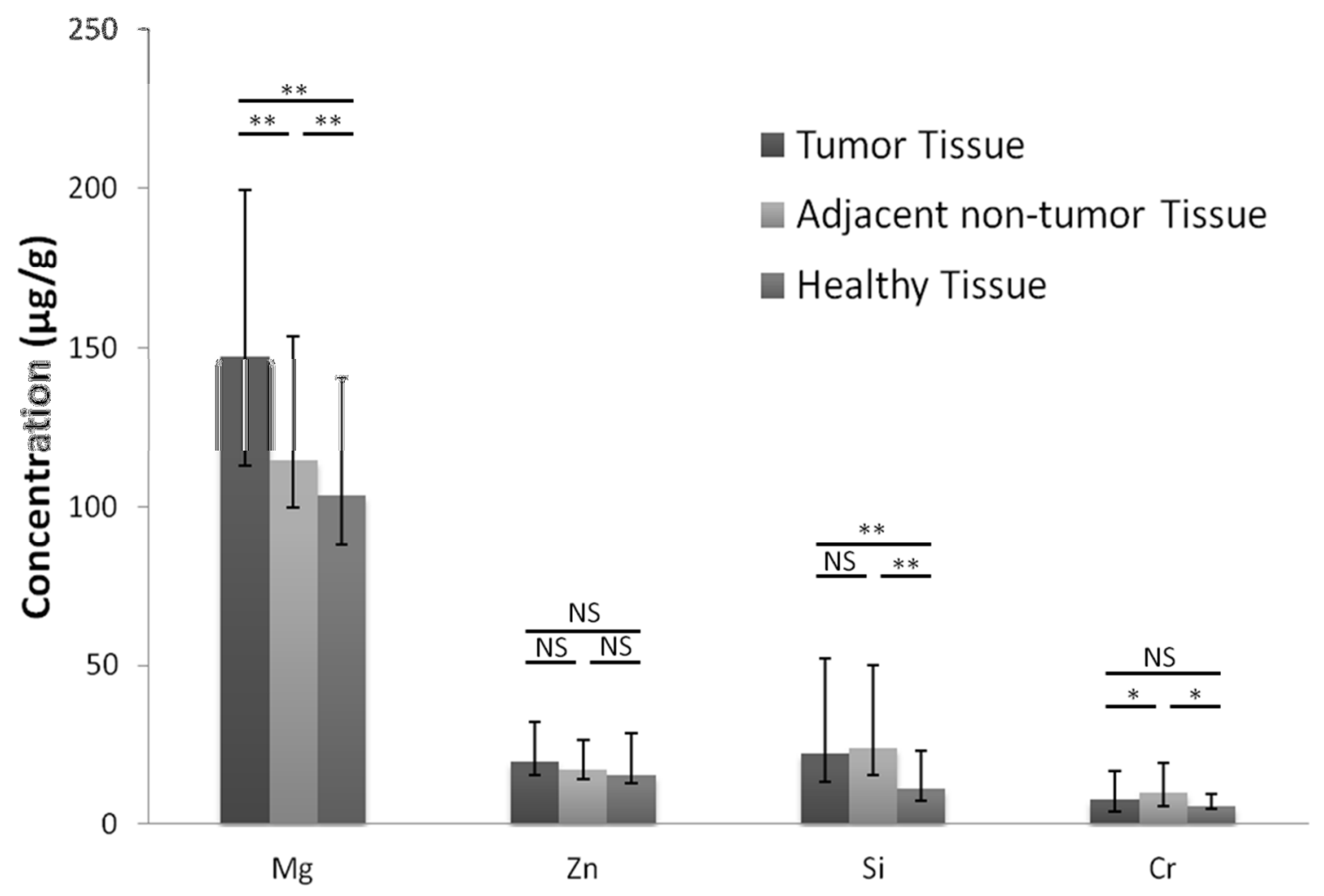

Figure 1: Median concentrations of $\mathrm{Mg}, \mathrm{Zn}, \mathrm{Si}$ and $\mathrm{Cr}$ expressed in $\mu \mathrm{g}$ of element per $\mathrm{g}$ of wet tissue (NS: not significant, ${ }^{*} p<0.05,{ }^{*} p<0.01$, Z-test, Wilcoxon test and MannWhitney test for independence) 


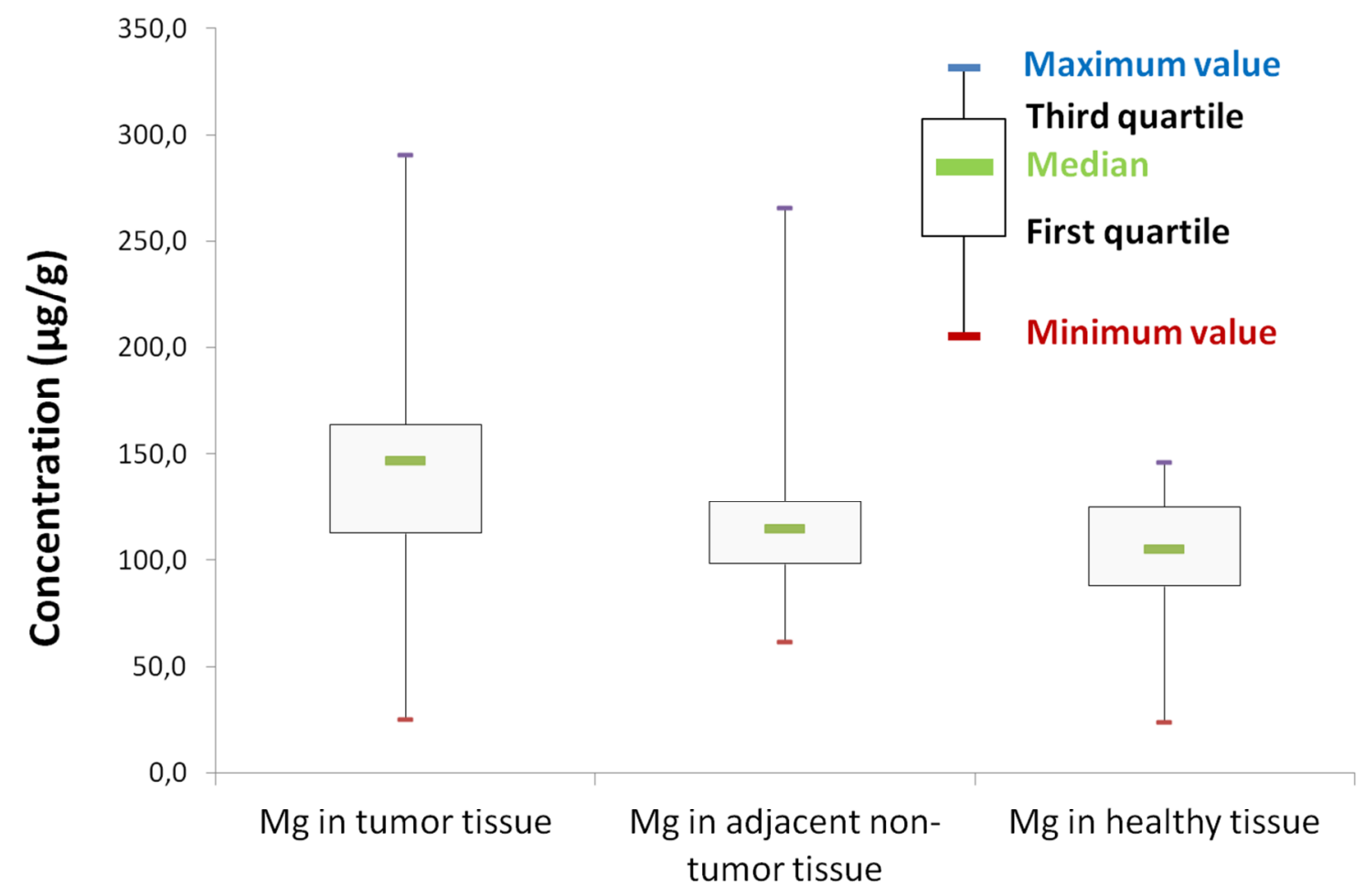

Figure 2: Median Mg concentrations expressed in $\mu \mathrm{g}$ per $\mathrm{g}$ of wet tissue 


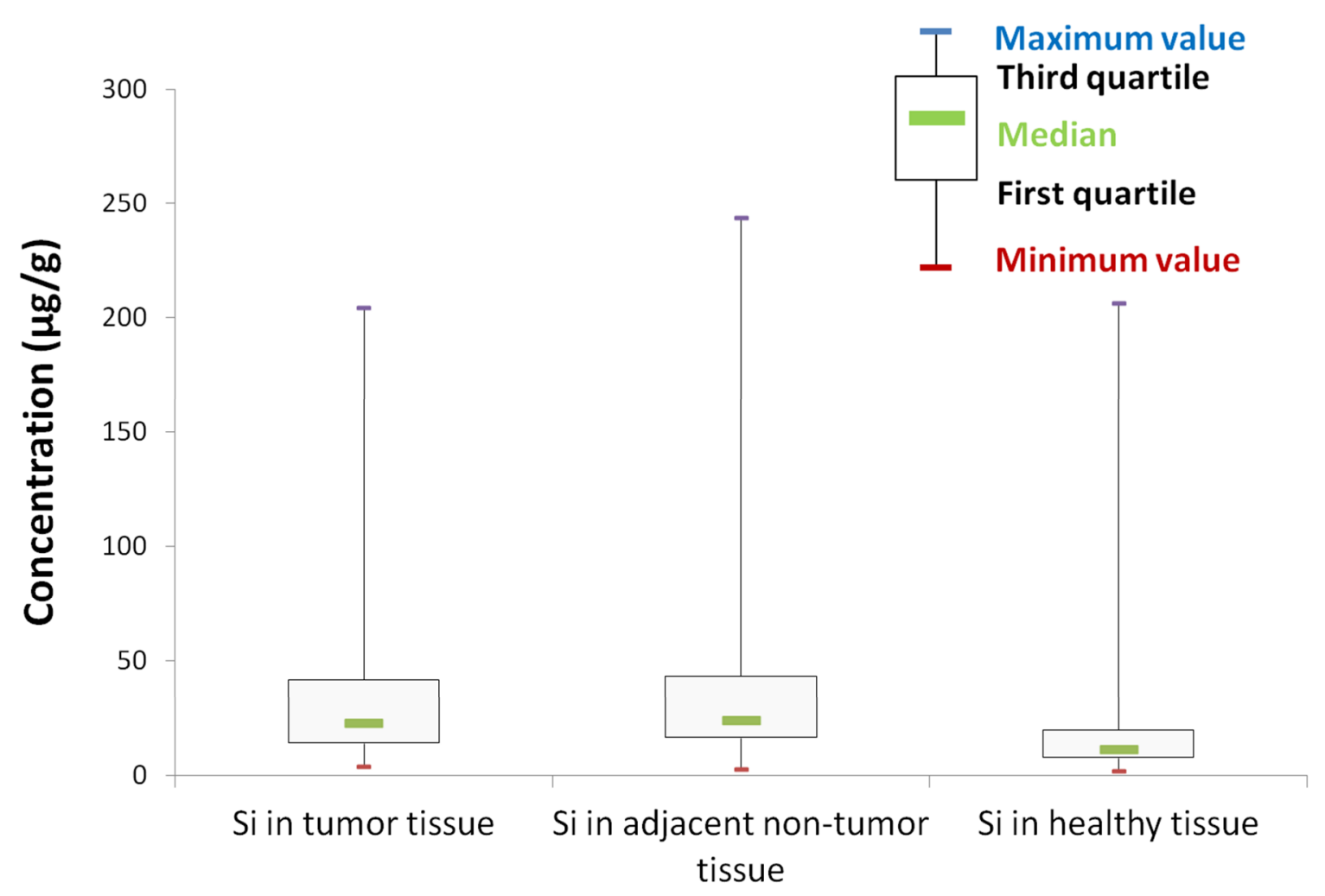

Figure 3: Median Si concentrations expressed in $\mu \mathrm{g}$ per $\mathrm{g}$ of wet tissue 


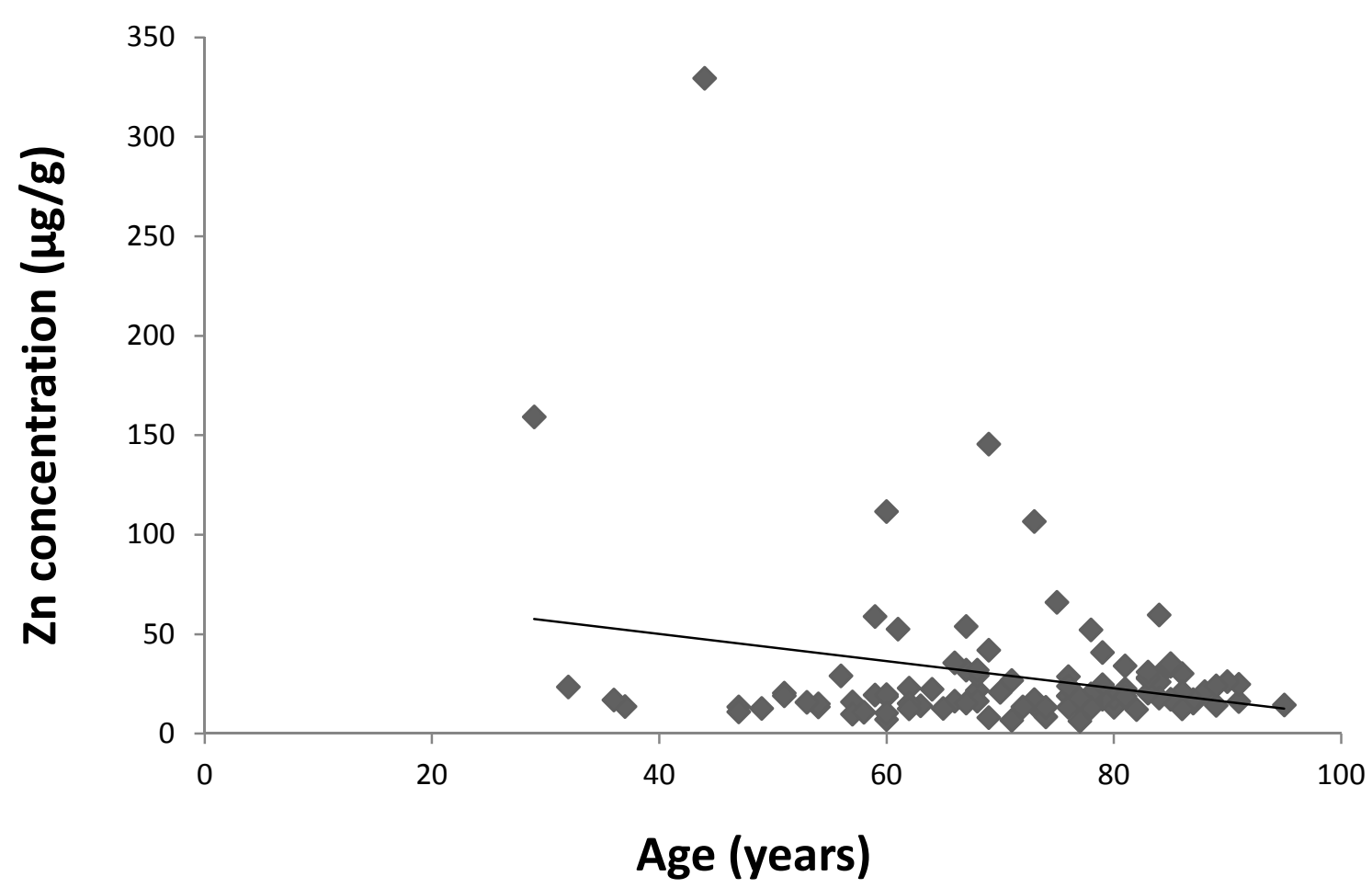

Figure 4: Correlation graph showing a weak inverse correlation between $\mathrm{Zn}$ concentration in colorectal tissue and patients age $(r=-0.21, p=0.03)$. 